\title{
Rehabilitation protocol after radial head arthroplasty - a single centre experience and narrative review of the literature
}

\author{
DOI: https://doi.org/10.5114/pq.2018.74705
}

\author{
Paweł Prostak', Cyprian Olchowy², Małgorzata Paprocka-Borowicz ${ }^{1}$ \\ ${ }^{1}$ Department of Physiotherapy, Wroclaw Medical University, Wroclaw, Poland \\ 2 Department of Radiology, Faculty of Medicine and Health Sciences University of Zielona Gora, Poland
}

\begin{abstract}
Radial head fractures are relatively common injuries - they represent about $1.5-4 \%$ of all fractures and approximately $1 / 3$ of fractures of the elbow. Nevertheless, treatment algorithms and rehabilitation plans in such injuries still remain controversial. One of the treatment methods is arthroplasty of the radial head. It is suitable for patients classified as II or III Mason type with concomitant instability and limited mobility of the elbow joint. Arthroplasty of the radial head aims at restoring joint stability, as well as early mobilization and rehabilitation. Currently in Poland, 200-250 alloplastic implantations of the radial head are performed per year (according to the Central Database of Arthroplasties) and this number is increasing annually. Consequently, physicians and physiotherapists may face that problem more frequently than only several years ago in their everyday clinical practice. For patients who underwent this type of surgery, there exists no unified, widely accepted rehabilitation protocol, neither in Poland nor worldwide. It has been proven that rehabilitation plays an important role in restoring the functioning of patients after arthroplasty of the radial head; however, it is difficult to find scientific reports and studies with therapeutic schemes that would provide guidelines for physiotherapy, active exercises, manual therapy, and muscle strength improving exercises. The aim of this review is to analyse and compare information about rehabilitation process after surgery of proximal radius that is available in the literature. The authors also present their own experience and results.

Key words: radial head fracture, radial head arthroplasty, rehabilitation protocol, elbow injury
\end{abstract}

\section{Introduction}

Both physicians and physiotherapists observe an increasing number of patients with fractures within the head of the radial bone in their clinical practice. According to statistics, these cover about $1.5-4 \%$ of all fractures and $1 / 3$ of fractures in the area of the elbow [1]. Currently, there are many methods for fixing fractures of the proximal epiphysis of the radius. They include both non-surgical methods, consisting of periodic immobilization of the broken limb, and surgical methods, such as partial or complete resection of the radial head, open reposition with internal fixation with the use of metal connectors, and radial head arthroplasty [2-4]. The qualification for a specific treatment method depends on many factors, including the nature of the fracture, the level of the elbow joint instability, or the age of the patient.

The elbow joint is a two-axial joint of the rotary-hinge type. Therefore, it requires intensive rehabilitation to prevent contractures that occur quickly in the postoperative period [3]. That is why it is very important to implement an adequate and effective mobility improvement process in the postoperative period. Along with the increasing trend in the number of radial head arthroplasty procedures, the question arises how to correctly conduct the protocol of rehabilitation in patients who undergo such surgery to improve the short- and long-term efficiency of the procedure.

In the paper, we presented rehabilitation protocols applied after radial head arthroplasty that are described in the litera- ture. The aim of this narrative article was to review the rehabilitative options for patients after radial head arthroplasty in the light of the current recommendations, safety issues, and our clinical experience.

\section{Search strategy}

We analysed reports and materials available in Polish and English language literature regarding methods of rehabilitation, recommendations, and accessible rehabilitation protocols after radial head arthroplasty. In the search, we used the Medline, ClinicalKey, and Academic Search Complete databases. The scope of our research included articles published between 2000 and 2017. The following keywords were used: radial head fracture, radial head arthroplasty, rehabilitation protocol, elbow injury, radial head surgery. In this narrative review, we included review papers and original articles with the preference for randomized trials with long-term follow-up.

\section{Results}

The current literature lacks unified recommendations for the rehabilitation protocol in patients after radial head arthroplasty. There is no universally recognized standardized rehabilitation program for Polish patients, either. In the current literature, there are only 2 detailed reports on the rehabilitation protocols for patients after radial head arthroplasty $[5,6]$. Those protocols are presented in Table 1.

Correspondence address: Paweł Prostak, Department of Physiotherapy, Wroclaw Medical University, ul. Grunwaldzka 2, 50-355 Wrocław, Poland, e-mail: pawel.prostak@gmail.com 
Table 1. Rehabilitation protocols for patients after radial head arthroplasty

\begin{tabular}{|c|c|c|c|}
\hline Bhinderwala and Wani [5] & Pho et al. [6] & Ashwood et al. [7] & Program from authors' institution \\
\hline & $\begin{array}{l}\text { Pre-rehabilitation } \\
\text { Instructions about application of ice, } \\
\text { home exercise program; discussion } \\
\text { about basic progression of rehabilita- } \\
\text { tion and patient expectations }\end{array}$ & $\begin{array}{l}\text { Pre-rehabilitation } \\
\text { Injury protection with immobilization; } \\
\text { instructions about postoperative } \\
\text { rehabilitation goals and plans }\end{array}$ & \\
\hline $\begin{array}{l}\text { Week } 1 \\
\text { Active assisted shoulder flexion, } \\
\text { extension, abduction, and rotations; } \\
\text { elbow flexion extension, forearm } \\
\text { pronation, wrist flexion extension, } \\
\text { radial and ulna deviation, stretching } \\
\text { exercises, mobilization of distal } \\
\text { radioulnar and radiocarpal joint }\end{array}$ & $\begin{array}{l}\text { Inpatient (days } \mathbf{0 - 4 )} \\
\text { Arm elevated in a sling on a pole } \\
\text { to prevent oedema and hematoma; } \\
\text { full flexion and extension; } \\
\text { cryotherapy in between sessions }\end{array}$ & $\begin{array}{l}\text { Immobilization (days } \mathbf{3 - 5} \text { ) } \\
\text { Pain and oedema control; fracture } \\
\text { site protection with posterior splint } \\
\text { or compression bandage; minimizing } \\
\text { cardiovascular deconditioning; } \\
\text { maintenance of range in joints } \\
\text { around the affected region; } \\
\text { contractures prevention }\end{array}$ & $\begin{array}{l}\text { Period I (weeks } 0-1 \text { ) } \\
\text { Immobilization of the upper limb } \\
\text { in the orthosis or plaster splint in the } \\
\text { neutral position; anti-oedematous } \\
\text { exercises }-20 \text { repetitions every hour, } \\
\text { active wrist and shoulder exercises } \\
\text { for } 4-5 \text { minutes } 3-4 \text { times a day, } \\
\text { local cryotherapy } 3-4 \text { times a day } \\
\text { every } 4 \text { hours for } 3 \text { minutes }\end{array}$ \\
\hline $\begin{array}{l}\text { Weeks } \mathbf{2 - 4} \\
\text { Scar tissue mobilization and } \\
\text { myofascial release, flexion; } \\
\text { extension, pronation, and supination } \\
\text { against an unyielding resistance } \\
\text { imparted by the therapist; static } \\
\text { and isometric stretching given to the } \\
\text { elbow flexors, extensors, pronators, } \\
\text { and supinators; strengthening } \\
\text { of shoulder and wrist muscles }\end{array}$ & $\begin{array}{l}\text { Outpatient phase } 1 \text { (to week 4) } \\
\text { Active elbow and wrist flexion, prona- } \\
\text { tion, and supination and active as- } \\
\text { sisted elbow flexion; shoulder flexibil- } \\
\text { ity exercises }\end{array}$ & $\begin{array}{l}\text { Phase I - maximum protection } \\
\text { phase (weeks 1-3) } \\
\text { Active assistive flexion/extension } \\
\text { and pronation/supination with sticks } \\
\text { or pulleys; cardiovascular conditioning; } \\
\text { increase in mobility to tolerance; } \\
\text { prevention of stiffness; CPM }\end{array}$ & $\begin{array}{l}\text { Period II (weeks 1-3) } \\
\text { No rigid immobilization, minimization } \\
\text { of strain on the operated upper limb } \\
\text { with the use of a sling; active and } \\
\text { passive exercises with the assistance } \\
\text { of a therapist; flexion, extension } \\
\text { of the elbow joint, pronation and } \\
\text { supination of the forearm to the } \\
\text { border of pain } 4-5 \text { times a day; } \\
\text { scar and fascial mobilization } 4-5 \\
\text { times a day; isometric exercises } \\
3 \times 30 \text { seconds with } 1 \text {-minute breaks; } \\
\text { local cryotherapy } 3-4 \text { times a day } \\
\text { every } 4 \text { hours for } 3 \text { minutes }\end{array}$ \\
\hline \multirow[t]{2}{*}{$\begin{array}{l}\text { Weeks } 4-8 \\
\text { In addition to exercises from weeks } \\
\text { 2-4: resistance exercises; strengthen- } \\
\text { ing biceps and triceps muscles; } \\
\text { resisted exercises (flexion, scaption, } \\
\text { abduction) for the shoulders, elbow } \\
\text { flexion and extension; forearm supi- } \\
\text { nation and pronation }\end{array}$} & $\begin{array}{l}\text { Outpatient phase } 2 \text { (weeks 5-8) } \\
\text { Shoulder elbow and wrist ROM; } \\
\text { at } 6 \text { weeks can add active extension; } \\
\text { gentle isometric and isotonic wrist } \\
\text { flexion/extension and elbow flexion } \\
\text { strengthening; biceps strengthening } \\
\text { with supported elbow; no elbow } \\
\text { extension strengthening }\end{array}$ & $\begin{array}{l}\text { Phase II - moderate protection } \\
\text { phase (weeks 4-6) } \\
\text { Active flexion/extension and prona- } \\
\text { tion/supination of the elbow; active } \\
\text { flexion, extension, pronation, supina- } \\
\text { tion with a wand or pulleys; pulleys } \\
\text { with eccentric control during flexion/ } \\
\text { extension; isometrics - flexion, exten- } \\
\text { sion, pronation, supination; gentle } \\
\text { stretching with inhibition/elongation } \\
\text { techniques or joint mobilization to } \\
\text { increase ROM }\end{array}$ & $\begin{array}{l}\text { Period III (weeks 3-6) } \\
\text { Immobilization with a sling; active- } \\
\text { passive exercises with the assistance } \\
\text { of a therapist; flexion, extension } \\
\text { of the elbow joint; pronation and } \\
\text { supination of the forearm to the } \\
\text { border of pain } 6-7 \text { times a day, at } \\
\text { least } 20 \text { minutes; increasing ROM } \\
\text { and muscle strength; isometric exer- } \\
\text { cises - } 20-30 \text { repetitions every hour; } \\
\text { active exercises and with resistance } \\
\text { dosed with the therapist's hand } \\
\text { aiming for } 10 \text { repetitions of a given } \\
\text { movement } 3-4 \text { times a day; } \\
\text { functional exercises, manual, PNF } \\
\text { method elements - at least } 2-3 \text { times } \\
\text { a day for } 20 \text { minutes; mobilization } \\
\text { of the scar; gentle stretching exer- } \\
\text { cises and post-isometric relaxation } \\
\text { after each series of exercises, local } \\
\text { cryotherapy after each series of } \\
\text { exercises for } 4-5 \text { minutes }\end{array}$ \\
\hline & $\begin{array}{l}\text { Outpatient phase } 3 \text { (weeks 9-16) } \\
\text { Maintenance flexibility program; } \\
\text { progressive isotonic resistance } \\
\text { including elbow extension; progress } \\
\text { to functional use }\end{array}$ & $\begin{array}{l}\text { Phase III - minimum protection } \\
\text { phase (weeks 6-12) } \\
\text { Resistive exercises: standing with } \\
\text { weights, theraband resisted exercises } \\
\text { (flexion, extension, pronation, supina- } \\
\text { tion); self-stretching: flexion/exten- } \\
\text { sion, pronation/supination, shoulder } \\
\text { and wrist flexion/extension, ulnar } \\
\text { and radial deviation; elbow extension } \\
\text { with radial deviation; elbow flexion } \\
\text { with ulnar deviation; intensive } \\
\text { isotonic flexion/extension, pronation/ } \\
\text { supination while standing or perform- } \\
\text { ing ADLs; open and closed-chain } \\
\text { exercises }\end{array}$ & $\begin{array}{l}\text { Period IV (weeks 6-8) } \\
\text { Upper limb without immobilization } \\
\text { with a sling; increasing ROM, striving } \\
\text { for a full range of movement - } \\
\text { exercises series } 4-5 \text { times a day } \\
\text { for } 30 \text { minutes; increasing muscle } \\
\text { strength; exercises with counter- } \\
\text { weights, tapes, pumps next to the } \\
\text { wall } 4-5 \text { times a day for } 10 \text { minutes; } \\
\text { functional therapy, PNF } 4-5 \text { times } \\
\text { a day for } 10-15 \text { minutes, local cryo- } \\
\text { therapy after each series of exercises } \\
\text { for } 4-5 \text { minutes; returning to daily } \\
\text { functioning }\end{array}$ \\
\hline $\begin{array}{l}\text { Home exercise program } \\
\text { Started at week } 2\end{array}$ & $\begin{array}{l}\text { Home exercise program } \\
\text { Started at week } 2\end{array}$ & & $\begin{array}{l}\text { Home exercise program } \\
\text { Started at week } 2\end{array}$ \\
\hline
\end{tabular}


In the available reports, the topic of the mobility improvement process is often discussed superficially, without details which could be used in clinical practice. Despite claims concerning the importance of the post-surgery rehabilitation for the healing process in patients after radial head arthroplasty, the available papers lack specific recommendations or indications. Many authors [5, 6, 8, 9] suggest that the rehabilitation protocol for patients undergoing surgery may be similar to that advocated after conservative treatment.

The review of the literature allows to create general recommendations for rehabilitation in patients after radial head arthroplasty:

1. Early start of rehabilitation - preferably on the $2^{\text {nd }}$ day after the surgery $[5,7,10]$.

2. Maintaining the immobilization of the elbow joint for a maximum of $2-3$ weeks after surgery $[5,7]$.

3. At least $6-8$ weeks of rehabilitation, but there is a lack of strict indications for the usage of physical therapy (except for cryotherapy) $[5,7,10]$.

4. During the initial period of convalescence (up to 3-4 weeks after surgery), forced passive and resistance exercises are not recommended. Intensive supination should be avoided during the first 2 postoperative weeks, as this further contributed to the decreased stability of the elbow joint.

In our institution, we developed a protocol for patients who had undergone radial head arthroplasty on the basis of the data from the literature and our clinical experience. The protocol consists of 4 periods of mobility improvement, presented in Table 1, in comparison with protocols from the literature, and accompanied by home exercises performed independently.

Patients are advised to perform the following exercises at home:

- from week 2 after the operation: active-passive flexion, straightening of the elbow joint (20 repetitions at least 4-5 times a day), exercises of pronation and supination of the forearm (20 repetitions $4-5$ times a day) after prior instruction from a physiotherapist, and also gentle stretching exercises after each series;

- after 4 weeks from the moment of operation: as above, and also: exercises increasing muscle strength with the use of a 0.5 -litre bottle of water, 3 times a day, 5-10 repetitions at the beginning, with gradual increase with the increasing muscle force; exercises performed in front of a mirror with feedback - flexion, extension, supination, and pronation (40 repetitions 3 times a day) and with cold compresses for 5 minutes after each sequence of exercises.

\section{Discussion}

Despite the fact that radial bone fractures cover $1 / 3$ of injuries within the elbow joint $[5,11]$, proper treatment of fractures in this region is still a field of many disputes and controversies. These mainly concern operating orthopaedic treatment. The lack of standards in the above-mentioned area also leads to difficulties in establishing guidelines regarding rehabilitation protocols.

The planning of the correct process of surgical and rehabilitation treatment is dictated by the knowledge of the mechanism of injury and the role of damaged anatomical structures in the biomechanics of the elbow joint $[4,12,13]$. The fractures in the area of the radial bone head occur most often as a result of falling on a bent elbow joint during the abduction of the shoulder or during injuries of the 'crooked mechanism' of the elbow joint $[11,14]$. Less often, fractures are caused by direct injuries in this area. Bone trauma is most often accompanied by soft tissue injuries, which include structures such as annular ligament, medial and lateral collateral ligaments, and the joint capsule [3, 11, 12, 15]. In the case of such multi-traumatic injuries, the radial head takes the main stabilizing role in the elbow [11]. It is a factor that encourages orthopaedists to attempt to connect the broken head of the radial bone or replace it with a prosthesis. There is a definite departure from resection of broken bone fragments $[11,13,15,16]$.

While determining the method of surgical treatment, the Mason's classification is used. Type I fractures account for about $82 \%$ of injuries and are treated conservatively. The indications for surgical treatment are fractures of II-IV type with the displacement of fragments, limitation of mobility, and elbow instability $[1,12,17,18]$. Factors that influence the decision to implant a radial head prosthesis include a large number of fractured fragments (more than 3 fragments), the risk of osteonecrosis after osteosynthesis, fracture of the head associated with dislocation within the radial-ulnar joint, and the patient's age (in younger patients, osteosynthesis of the broken head is preferred) $[1,8,12,14]$.

The main assumptions of radial head arthroplasty include the recovery of the physiological trajectory in the brachialradial part of the elbow joint, recovery of the biomechanical function of the natural radial head, recovery of joint stability and the ability to transmit forces acting on the elbow joint $[3,14,19]$. The selection of the correct diameter of the head implant, its height, and its correct axial alignment is important for the end result of the treatment $[17,20]$.

Radial head bone arthroplasty allows for a rapid start of rehabilitation [5]. Owing to a high risk of contracture formation in the elbow joint during immobilization, attention is paid to an immediate start of rehabilitation after surgery in the majority of studies. However, Pho et al. [6] recommend to avoid active supination, pronation, weight lifting, and pushing movements during the first 2 weeks after surgery because this may disturb the stability of the elbow joint $[10,19]$. Therefore, postoperative management requires maintaining a balance between the protection of the reconstructed connective tissue structures and achieving proper joint mobility [5, 7, 9]. For the immediate postoperative period, the majority of available literature recommends immobilization of the operated limb in a 90-degree flexion of the elbow and regular active exercises with the assist of a therapist [2, 9].

The presence of an experienced therapist, who properly conducts the rehabilitation protocol, has a significant impact on the regain of mobility, strength, and functionality in the area of the elbow [3, 7, 20-22]. However, documented manual therapy techniques for patients who had undergone radial head arthroplasty are scarce. Reports available in the literature indicate only methods of fascial mobilization and the proprioceptive neuromuscular facilitation method.

The patient's rehabilitation process should be carefully monitored by a physiotherapist. It is best to use standardized and objective functional tests. In the analysed literature, the reference was most frequently made to the Mayo Elbow Performance Score (MEPS) or the Disabilities of the Arm, Shoulder and Hand Score (QuickDASH) [1, 2, 5, 13, 23, 24]. These allow to evaluate the mobility improvement on an ongoing basis and modify it on the basis of the obtained results.

The dependence of the treatment effects on the implemented rehabilitation process in patients who had undergone radial head arthroplasty is unquestionable [5, 12, 14]. However, the inconsistency of available rehabilitation protocols allows to presume that conducting randomized trials on the mobility improvement scheme would provide even better 
knowledge about mobility and functionality regain in the operated joints.

\section{Limitations}

The main limitation of our analysis is the small amount of available literature regarding rehabilitation after radial head arthroplasty. The short observation period in some reports additionally reduced the possibility to include available protocols in our research. There were also rehabilitation schemes in which the authors did not provide any effects of the mobility improvement.

\section{Conclusions}

1. Rehabilitation of patients who had undergone radial head arthroplasty requires more attention and further study.

2. Most reports from the literature focus on the early initiation of rehabilitation, avoidance of long-term immobilization, and treatment within the first 2-3 weeks in the post-operative period as a protective period, without overcharging the operated joint; however, the minimum period of the rehabilitation protocol should last 6-8 weeks.

3. The literature also draws attention to the significant role of a therapist in the process of mobility improvement.

4. Because of the increasing number of patients who undergo postoperative rehabilitation due to radial head arthroplasty, there is a need to extend the research in this area to evaluate the rehabilitation process in accordance with the evidence-based medicine recommendations.

\section{Disclosure statement}

No author has any financial interest or received any financial benefit from this research.

\section{Conflict of interest}

The authors state no conflict of interest.

\section{References}

1. Chwedczuk B, Piekarczyk P, Kwiatkowski K, Piatkowski K. Surgical treatment of radial head fractures: outcomes and complications. Ortop Traumatol Rehabil. 2016;18(5): 435-444; doi: 10.5604/15093492.1224617.

2. Chien HY, Chen AC, Huang JW, Cheng CY, Hsu KY. Shortto medium-term outcomes of radial head replacement arthroplasty in posttraumatic unstable elbows: 20 to 70 months follow-up. Chang Gung Med J. 2010;33(6):668678.

3. Sanchez-Sotelo J, Morrey M. Complex elbow instability: surgical management of elbow fracture dislocations. EFORT Open Rev. 2016;1(5):183-190; doi: 10.1302/20585241.1.000036.

4. Nalbantoglu U, Kocaoglu B, Gereli A, Aktas S, Guven O. Open reduction and internal fixation of Mason type III radial head fractures with and without an associated elbow dislocation. J Hand Surg. 2007;32(10):1560-1568; doi: 10.1016/j.jhsa.2007.09.016.

5. Bhinderwala S, Wani S. A case study of radial head replacement rehabilitation. J Evidence-Based Physio Research. 2017;1(1):37-41.

6. Pho C, Godges J, Linda L. Total elbow arthroplasty and rehabilitation. 2017.

7. Ashwood N, Bain GI, Unni R. Management of Mason type-III radial head fractures with a titanium prosthesis, ligament repair, and early mobilization. J Bone Joint Surg Am. 2004;86-A(2):274-280.

8. Shore BJ, Mozzon JB, MacDermid JC, Faber KJ, King GJ. Chronic posttraumatic elbow disorders treated with metallic radial head arthroplasty. J Bone Joint Surg Am. 2008;90(2):271-280; doi: 10.2106/JBJS.F.01535.

9. Gugliotti M. The use of mobilization, muscle energy technique, and soft tissue mobilization following a modified radical neck dissection of a patient with head and neck cancer. Rehabilitation Oncology. 2011;29(1):3-8.

10. Pomianowski S, Kędzior K, Skalski K, Świeszkowski W. If bipolar radial head is a good solution for radial head replacement? Lecture notes of the ICB seminars. Biomechanics. Customized endoprostheses. Design, manufacture and clinical applications. Warszawa; 2002; 38-47.

11. Rosenblatt Y, Athwal GS, Faber KJ. Current recommendations for the treatment of radial head fractures. Orthop Clin North Am. 2008;39(2):173-185; doi: 10.1016/j.ocl. 2007.12.008.

12. Meena PK, Gaba S, Bobade S, Verma R, Borade A, Sonaje J, et al. Functional outcome of resection versus reconstruction in Mason II-III radial head fractures; a short-term prospective study. Bull Emerg Trauma. 2017;5(4):266-272; doi: 10.18869/acadpub.beat.5.4.453.

13. Lópiz Y, González A, García-Fernández C, García-Coiradas J, Marco F. Comminuted fractures of the radial head: resection or prosthesis? Injury. 2016;47 Suppl 3:S29S34; doi: 10.1016/S0020-1383(16)30603-9.

14. Marinelli A, Guerra E, Ritali A, Cavallo M, Rotini R. Radial head prosthesis: surgical tips and tricks. Musculoskelet Surg. 2017;101(Suppl 2):187-196; doi: 10.1007/s12306017-0504-x.

15. Schneeberger AG, Sadowski MM, Jacob HA. Coronoid process and radial head as posterolateral rotatory stabilizers of the elbow. J Bone Joint Surg Am. 2004;86-A(5): 975-982.

16. Kodde IF, Kaas L, Flipsen M, van den Bekerom MP, Eygendaal $\mathrm{D}$. Current concepts in the management of radial head fractures. World J Orthop. 2015;6(11):954-960; doi: 10.5312/wjo.v6.i11.954.

17. Tarallo L, Mugnai R, Rocchi M, Capra F, Catani F. Mason type III radial head fractures treated by anatomic radial head arthroplasty: is this a safe treatment option? Orthop Traumatol Surg Res. 2017;103(2):183-189; doi: 10.1016/j.otsr.2016.10.017.

18. Papatheodorou LK, Rubright JH, Heim KA, Weiser RW, Sotereanos DG. Terrible triad injuries of the elbow: does the coronoid always need to be fixed? Clin Orthop Relat Res. 2014;472(7):2084-2091; doi: 10.1007/s11999-0143471-7.

19. Ring D, Psychoyios VN, Chin KR, Jupiter JB. Nonunion of nonoperatively treated fractures of the radial head. Clin Orthop Relat Res. 2002;398(398):235-238; doi: 10.1097/00003086-200205000-00032.

20. Iftimie PP, Calmet GJ, de Loyola GF I, Gonzalez Pedrouzo JE, Giné GJ. Resection arthroplasty for radial head fractures: long-term follow-up. J Shoulder Elbow Surg. 2011;20(1):45-50; doi: 10.1016/j.jse.2010.09.005.

21. Dou Q, Yin Z, Sun L, Feng X. Prosthesis replacement in Mason III radial head fractures: a meta-analysis. Orthop Traumatol Surg Res. 2015;101(6):729-734; doi: 10.1016/j.otsr.2015.06.015.

22. King GJ. Management of comminuted radial head fractures with replacement arthroplasty. Hand Clin. 2004; 20(4):429-441; doi: 10.1016/j.hcl.2004.06.003. 
23. Chen X, Wang SC, Cao LH, Yang GQ, Li M, Su JC. Comparison between radial head replacement and open reduction and internal fixation in clinical treatment of unstable, multi-fragmented radial head fractures. Int Orthop. 2011;35(7):1071-1076; doi: 10.1007/s00264-010-1107-4.

24. Gummesson C, Ward MM, Atroshi I. The shortened disabilities of the arm, shoulder and hand questionnaire (QuickDASH): validity and reliability based on responses within the full-length DASH. BMC Musculoskelet Disord. 2006;7(1):44; doi: 10.1186/1471-2474-7-44. 